4. Strive to create a work environment that is open, trusting, and fun. Encourage new ideas and initiative.

5. Provide information about upcoming products and strategies, how the company makes and loses money, and how each employee fits into the overall plan.

6. Involve employees in decisions, especially those decisions that directly affect them.

7. Encourage employees to have a sense of ownership in their work and their work environment.

8. Create a partnership with each employee, giving them a chance to grow and learn new skills. Show them how you can help them meet their goals within the context of meeting the organization's goals.

9. Celebrate successes of the company, the department, and the individuals in it. Take time for team- and morale-building meetings and activities.

10. Use performance as the basis for recognizing, rewarding, and promoting people. Deal with low and marginal performers so that they improve their performance or leave the organization ${ }^{2}$.

\section{REVIEW OF EARLIER WORKS}

Maryam T. Abbah (2014) ${ }^{3}$ in his article explores the indispensability of employee motivation in effective organizational management, efficiency and relevance of motivation in the success of organizational management. It also identifies and explains the factors that affect employee motivation, the benefits of employee motivation in Nigerian organizations, some theories of motivation and the significant link between effective organizational management and employee motivation in Nigerian organizations, both the public and the private. For the fact that employee motivation is an intricate and sophisticated subject, once applied in the right way an organization is bound to achieve a long-lasting success. For Nigerian managers to have an understanding of employee motivation, they were discuss the concept of motivation, organizational management, differences in individual needs and the variety of motivational factors and the changes in priorities of these factors overtime. The necessity of this work is situated in it provision of solutions to Nigerian employees' redundant attitude to work and its consequences.

\section{Dr. Olivia Anku-Tsede and Ernestina Kutin}

(2013) ${ }^{4}$ in their paper examines the concept of total reward and its application in motivating employees in Ghana. Total reward as an integral element of reward management is the combination of financial and nonfinancial rewards given to employees in exchange for their efforts. The aim of total reward is to maximize the combined impact of a wide range of reward elements on motivation, commitment and job engagement. Hence, total reward embraces everything that employees' value in the employment relationship. In spite of the growing need to pay attention to the concept of total reward, it appears most Ghanaian organisations place more emphasis on traditional rewards that are typically extrinsic and financial in nature. Thus, most Ghanaian organisations pay too much attention to financial rewards at the expense of non-financial rewards. This paper thus examines existing literature on the concept of total reward to determine whether the adoption of total reward strategy could be the answer to corporate Ghana in its bid to obtain maximum efforts from employees.

Quratul-Ain Manzoor (2012) ${ }^{\mathbf{5}}$ in his article the main purpose of this paper is to identify the factors that effects employee motivation and examining the relationship between organizational effectiveness and employee motivation. The study focuses on the practice and observance of the two central factors, empowerment and employee recognition for enhancing employee motivation which leads to organizational effectiveness. The organizations should design their rules, policies and organizational structures that give space to the employee to work well and appreciate them on their tasks fulfillment and achievements. This will surely lead to organizational growth. and also focus there exists a positive relationship between employee motivation and organizational effectiveness. The more the employees are motive to tasks accomplishment higher will the organizational performance and success.

Andrea Pohanková (2010) ${ }^{\mathbf{6}}$ in his article investigates about the importance and relevance of the changes for the organization. At first it is necessary to define the term decision-making and motivation, because both of them relate to management of changes. Decisionmaking is the most important function of management and the decision may mean that more or less change is needed. Employee's motivation influence decisionmaking process itself and change management. Motivated employees more easily accept the planned changes and they are more inclined to improvement 
proposal. Organizational changes are not implemented without problems. Often there are barriers that may negatively affect the planned changes or prevent their realization. In conclusion, it is suggested the importance of removing barriers that relate to the personality of employees or the functioning of the organization. Motivation is an important element in any change in the organization and influences the whole process of change management and the organization.

\section{Mohammed Javed Kalburgi and Dinesh.G.P} (2010) $^{7}$ in their article discuss many factors that play into the concept of employee motivation. The first necessary step is to determine what motivational tools will actually be effective in each particular situation. Some tools may work for some companies, but not for others and vice versa. It is important to note that the decisions dealing with motivation are based upon several theories. The workers were positively affected toward higher productivity with the provision of regular promotion, assurance of adequate job security and bonus for excellent performance. Nevertheless monetary incentives and rewards do not exert stronger influence on workers than any form of motivational factor. The organization should encourage initiative and creativity by allowing for some flexibility in application of rules and regulation.

CA Arnolds and DJL Venter (2007) ${ }^{\mathbf{8}}$ in their study discussed biggest challenges that managers' face in executing business strategies to achieve competitive advantage is the employment of motivational techniques that build wholehearted commitment to operating excellence. Much confusion however still exists on the question of which rewards really motivate employees. This study investigates which rewards motivate lower-level employees in both manufacturing and clothing retail firms. The results show that the most important individual motivational reward for blue-collar employees is paid holidays and for frontline employees, retirement plans. The most important motivational reward category for both bluecollar and frontline employees is fringe benefits (paid holidays, sick leave and housing loans).

\section{RESEARCH GAP}

Though the literature reviewed some of the qualified literature to meet the study intent has facilitate the researchers to identify the research gap. There are number of papers highlighting the need for Motivation tools. But there is a failure on part of the studies to develop a comprehensive framework to incorporate various dimensions of management approach to have $\mathrm{HR}$ as an integral part of value creation practices especially where it comes to strategic HR manager role in organization; where, the employee motivation Tools and its create quality work enhance in organization. The present study attempts to make an analysis of Contemporary Motivation tools adopted by Strategic HR Managers such as intrinsic motivation, extrinsic motivation and combined motivation tool for improve employee work performance in the organization. This information would provide for betterment of ensure Motivation tools adopted by Strategic HR Managers and ensure efficiency in value creation process.

\section{OBJECTIVES OF THE STUDY}

The general objective of the study is to investigate the place of motivation in increasing organizational productivity among employee, Strategic HR managers and organization. The following objectives are:

To study Contemporary Motivation tools adopted by Strategic HR Managers for employees in organization.

To determine the factors that increase intrinsic motivation and extrinsic motivation of employees in an organization

To know the relationship between employees motivation by strategic HR manager for increases the productivity and organizational performance.

\section{CONTEMPORARY MOTIVATION TOOLS}

Tools for motivating employees fall into two basic categories. The first is external or extrinsic. These tools deal with physical or monetary rewards, such as bonuses or child care. The second category is internal or intrinsic. These rewards meet a psychological or personality need of employees, such as feelings of validation or pride in a job well done. Although many companies focus on external motivators, addressing internal motivators is equally important because external motivators tend to become less effective over time.

\section{INTRINSIC \& EXTRINSIC MOTIVATION TOOLS USED BY HR MANAGERS}

Workplace motivation can be broken down into two categories: intrinsic and extrinsic. Intrinsic motivation is the desire to accomplish goals and develop professionally. Extrinsic motivation involves work factors such as pay and promotions. In some cases, 
intrinsic and extrinsic motivation can be combined, such as when a promotion leads to a pay raise as well as welcome additional responsibility. Managers need to understand the basic intrinsic and extrinsic motivators needed to inspire employees.

\section{$>$ Challenge}

Employees will sometimes get involved in their career of choice because they appreciate the challenges that come with it. Managers can use this intrinsic motivation of searching for a challenge to motivate employees to succeed. By working with employees to create goals and develop a career path, managers satisfy that need for a challenge while rewarding the employee with access to greater corporate opportunity.

\section{Satisfaction}

When managers make the work employees do rewarding, it adds a level of intrinsic motivation that can be a powerful motivator. To build a sense of job satisfaction, managers need to help employees understand how the results of their work benefit the company, or the community. For example, managers can motivate city streets workers by reminding them that plowing the streets allows school buses and emergency vehicles to navigate roads safely. When streets employees understand the magnitude of their work, they develop a strong sense of job satisfaction.

\section{$>$ Responsibility}

Responsibility involves the delegation of authority that managers and companies give to employees. Employees generally associate an increase in responsibility with an increase in pay, and this extrinsic form of motivation can help identify managerial candidates. An increase in responsibility can mean taking on the leadership of a team or moving to a higher position within the company. Using responsibility as an extrinsic motivator is all about developing a career path for employees.

\section{$>\quad$ Work Tools}

An employee who develops confidence in the company's ability to be competitive in the marketplace can become a motivated staff member. An extrinsic motivator that helps develop confidence in the company is attention to providing quality and up-to-date work tools for the staff. Whether it is the latest in customer management software or the newest forklift technology for the warehouse, providing quality work tools acts as a strong external motivator ${ }^{9}$.

\section{Intrinsic Motivation Techniques for Employees}

Employees who feel their work is valued have an increased sense of motivation. Intrinsic motivation occurs when an individual is able to focus on internal drivers as the impetus for doing something. For example, an intrinsically motivated employee will stay late to finish every last detail of an important presentation. She does this not because she wants the overtime pay, as would be an example of an extrinsic motivator, but because she feels a personal sense of accomplishment in doing the job to the best of her abilities. Intrinsic motivators in the workplace grow when employees feel challenged, capable, valued and have a general enjoyment of their jobs.

\section{$>$ Challenging Work}

Employees who are challenged in a positive way become intrinsically motivate to push themselves to be their best. Providing challenging assignments and giving employees flexibility to make decisions about how they approach projects creates a sense of control. This control leads a sense of ownership in the project, and employees are motivated to succeed by a desire to step up to the challenge.

\section{Ability to Choose}

Employees have different core skills, different values and individualized approaches to completing tasks. Giving employees the opportunity to choose assignments best matched with their personal preferences and areas of strength is an internal motivator. Employees feel their skills are being used in the most effective way and the ability to select projects of personal interest increases the chances the final project will be successful.

\section{Opportunity for Advancement}

Employees who feel they have a bright professional future ahead of them are more intrinsically motivated than employees who feel they are stuck in a job that will never change or inspire them. Employees who see a clear path to career advancement have a vested interest in the company and are motivated to contribute to its success, and therefore, to their own success.

\section{Mentoring and Education}

Employees who are mentored and given the opportunity to expand their knowledge through participation in professional development seminars and training sessions feel an increased sense of worth. This internal motivator makes employees feel they are 
valued by the company, which makes them value the quality of their work.

\section{Regular Feedback}

Employees who know where they stand with regard to performance measurements feel more control over the stability of their jobs and the quality of their work. Taking time to give employees regular feedback and constructive criticism creates a system where employees feel they are able to constantly improve their performance.

\section{Participation in Decision Making}

Employees who are engaged in the corporate decision-making process are intrinsically motivated because they have a sense of camaraderie as well as a stake in the success of the company. Employees view themselves as being valued members of the collective team and that their intellect and input is noticed and appreciated $^{10}$.

\section{EXTRINSIC MOTIVATION TOOL USED BY HR MANAGER}

Extrinsic motivation comes from influences outside of the individual. In extrinsic motivation, the harder question to answer is where people get the motivation to carry out and continue to push with persistence ${ }^{11}$. Often these benefits are beyond the direct control of $\mathrm{H}$ $\mathrm{R}$ manager and are more often determined at an organizational level. However, effective managers should be supportive of colleagues motivated by extrinsic factors.

\section{$>$ Excellent Pay and Benefits (financial rewards)} Financial rewards are monetary incentives that an employee earns as a result of good performance. These rewards are aligned with organizational goals. When an employee helps an organization in the achievement of its goals, a reward often follows. All financial rewards are extrinsic. Extrinsic motivation is based on tangible rewards, such as pay raises, bonuses and paid time off. There are many different types of financial rewards a company can offer its employees. Pay increases and bonuses are a great way to reward employees; however, there are many other ways to financially reward an employee.

\section{$>$ Recognition and reward for performance}

Executives, operational chiefs and personnel managers must ensure that their systems of rewards and recognition are carefully aligned with overall strategic and operational goals. Rewards and recognition systems misaligned with corporate objectives can result in behavior that is not anticipated or desired by management. These unanticipated actions may be personally beneficial to front-line sales reps, manufacturing floor managers or even senior executives, yet they move the company away from its overall goals or cause systemic harm.

\section{Employee promotion}

Promotion is the advancement of an employee's rank or position in an organizational hierarchy system. Promotion may be an employee's reward for good performance, i.e., positive appraisal. Before a company promotes an employee to a particular position it ensures that the person is able to handle the added responsibilities by screening the employee with interviews and tests and giving them training or onthe-job experience. A promotion can involve advancement in terms of designation, salary and benefits, and in some organizations the type of job activities may change a great deal ${ }^{11}$.

\section{Monetary incentives}

Those incentives which satisfy the subordinates by providing them rewards in terms of rupees or Money has been recognized as a chief source of satisfying the needs of employee. Money is also helpful to satisfy the social needs by possessing various material items. Therefore, money not only satisfies psychological needs but also the security and social needs. Therefore, in many factories, various wage plans and bonus schemes are introduced to motivate and stimulate the employees to work.

Incentive is an act or promise for greater action. It is also called as a stimulus to greater action. Incentives are something which is given in addition to wagers. It means additional remuneration or benefit to an employee in recognition of achievement or better work. Incentives provide encourage or enthusiasm in the employees for better performance. It is a natural thing that nobody acts without a purpose behind. Therefore, a hope for a reward is a powerful incentive to motivate employees. Besides monetary incentive, there are some other stimuli which can drive a person to better. This will include job satisfaction, job security, job promotion, and pride for accomplishment. Therefore, incentives really can sometimes work to accomplish the goals of a concern. The need of incentives can be many:-

1. To increase productivity,

2. To drive or arouse a stimulus work,

3. To enhance commitment in work performance, 
4. To psychologically satisfy a person which leads to job satisfaction,

5. To shape the behavior or outlook of subordinate towards work,

6. To inculcate zeal and enthusiasm towards work,

7. To get the maximum of their capabilities so that they are exploited and utilized maximally ${ }^{12}$.

\section{CONCLUSION}

A motivated employees and HR managers are the valuable asset, who can deliver immense value to the organization in maintaining and strengthening it individual and organization growth. This paper concludes that employee motivation is an intricate and sophisticated subject; however, contemporary managers must face and deal with it to obtain organizational success. To enhance understanding of employee motivation, managers must recognize the imperativeness of employee motivation, its concepts, and differences in individual needs. Subsequently managers need to be aware of a variety of employee motivational factors and the changes in priorities of these factors overtime. Moreover, managers have to learn previous or current motivational programs, examples, and theories behind them because understanding of these fundamentals can enhance their ability to identify intrinsic and extrinsic tools system that can be matched with employee needs.

\section{References}

1. Boyett, H. Joseph, and Jimmie T. Boyett. (2000). World-class advice on managing and motivating people. Boyett and Associates. Available on the World Wide Web at http://www.jboyett.com/managing1.htm.

2. http://www.dummies.com/how-to/content/tenways-for-managers-to-motivate-employees.html, date 10/02/2015, time-12.30am

3. Maryam T. Abbah (2014) "Employee Motivation: The Key to Effective Organizational Management in Nigeria", IOSR Journal of Business and Management (IOSR-JBM)'e-ISSN: 2278-487X, p-ISSN: 2319-7668. Volume 16, Issue 4. Ver. I (Apr. 2014), PP 01-08
4. Dr. Olivia Anku-Tsede and Ernestina Kutin (2013) "Total Reward Concept: A Key Motivational Tool For Corporate Ghana", Business and Economic Research, ISSN 21624860 2013, Vol. 3, No. 2

5. Quratul-Ain Manzoor (2012) "Impact of Employees Motivation on Organizational Effectiveness", European Journal of Business and Management, ISSN 2222-1905 (Paper) ISSN 2222-2839 (Online), Vol 3, No.3, pp no-36to44

6. Andrea Pohanková (2010) "MOTIVATION AND DECISION-MAKING PROCESS IN MANAGING CHANGE WITHIN THE ORGANIZATION", Human Resources Management \& Ergonomics, Volume IV

7. Mohammed Javed Kalburgi and Dinesh.G.P (2010) "Motivation as a tool for productivity in Public sector unit", ASIAN JOURNAL OF MANAGEMENT RESEARCH (Online Open Access publishing platform for Management Research)(C Copyright 2010 All rights reserved Integrated Publishing association, Research Article ISSN $2229-3795$

8. CA Arnolds and DJL Venter (2007) "THE STRATEGIC IMPORTANCE OF MOTIVATIONAL REWARDS FOR LOWERLEVEL EMPLOYEES IN THE MANUFACTURING AND RETAILING INDUSTRIES", SA Journal of Industrial Psychology, 2007, 33 (3), 15-23, SA Tydskrif vir Bedryfsielkunde, 2007, 33 (3), 15-23

9. http://smallbusiness.chron.com/intrinsic-extrinsicmotivation-used-managers-10429.html, date$11 / 02 / 2015$, time-5.15pm

10. http://smallbusiness.chron.com/top-intrinsicmotivation-techniques-employees-17737.html, date-12/02/2015, time-4.30pm

11. http://en.wikipedia.org/wiki/Motivation, date11/02/2015, time-9.30am

12. http://www.managementstudyguide.com/motivati on_incentives.htm,date-09/02/2015,time $12.30 \mathrm{am}$ 